\title{
While you were sleeping
}

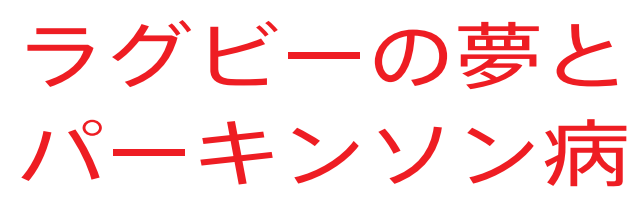

Nature Vol.437(1220-1222)/27 October 2005

眠っているあいだに、夢の内容にあわせて手足を大きく動かしてしまう人たちがいる。この症状にパーキンソン病治療 のヒントが隠されているとは思えないかもしれない。しかし、この睡眠障害の研究を通じて、パーキンソン病などの神 経変性疾患の進行についての新しい仮説が生まれている。Alison Abbott が報告する。

多くの夫婦は、警察ざたになることを恐 れて、だれにも話せずに苦しんでいる。 それでもなんとか睡眠障害のクリニッ クを訪ねた者は、奇妙な話を医師に語 りだす。睡眠神経学者のBrad Boeve は、ある夫婦が打ち明けた、とりわけ恐 ろしい夜の事件を思いだすという。そ れは、夫婦がベッドで眠っていたとき、 夫が突然、妻の頭をつかんで乱暴に振 り回し、たたきつけたかと思うと、急 に腕を突き上げたという話だった。

こうした行動は故意ではまったくな い。この困った行動は、眠っている人 が夢を実際に行動に表してしまうとい う病気の結果なのだ。この例では、夫 は夢のなかでラグビーをしていて、ト ライを決め、勝利の喜びで腕を突き上 げた。夫は目を覚ましてから、そう明 らかにした。

これは、Boeve がメイヨークリニッ ク (米国ミネソタ州ロチェスター) で調 べたたくさんの事例の 1 つにすぎない。 また、話はこうした睡眠障害とのつなが
りが明白な心的外傷だけにとどまらず、 睡眠障害がもっと深刻な事態をほのめ かしている可能性を Boeve は考えてい る。この睡眠障害をもつ者のかなりの割 合が、パーキンソン病か、それに密接に 関連した神経変性疾患になるからだ。

「こうした症状があり、恐れを抱いて いる人たちからのメールが毎週のよう に届く」とBoeve は話す。「レム睡眠 行動障害」(RBD) とよばれる睡眠障害 とパーキンソン病が関連しているかも しれないという考えは、医師にとって 判断がむずかしい倫理的問題を提起す る。しかし、パーキンソン病がどうし て起こり、ぞうすれば治療できるのか、 現在考えられている仮説をくつがえす 可能性もある。

睡眠障害には、不眠症から夢遊病ま でさまざまなものがあるが、慢性の RBD ほど奇妙で不安をかきたてるもの はあまりない。夜間の健康な睡眠では、 その 4 分の 1 が急速眼球運動 (REM= レム) 睡眠で、レム睡眠は眠っている
あいだ断続的に徐々に長くなりながら 繰り返される。また、レム睡眠中は夢 をみていて、そのあいだ随意筋は（絶 えずピクピクしている目の随意筋を除 き）一時的にまひしている。随意筋の まひをレム筋弛緩というが、こうして 随意筋がまひすることで、私たちは夢 を実際の行動に表すことはない。

RBD 患者にはこのレム筋弛緩が起こ らない。RBD 患者は夢の経過に沿って 手足を激しく動かし、別の人の頭をつ かむ例のように、複数の筋肉を同時に 使う動きを行う。RBD 患者の夢はいつ も鮮明で、格闘や何かに追われるといっ た内容が多い。専門家は、そうした夢 の内容は、物語に対応して動く手足の 動きに逆に影響を受けているものと考 えている。

\section{6 人のうち 18 人が}

RBD の症状は 1 年に 1 度だけ現れるこ ともあれば、ひと晚に 4、5 回出る場合 もある。今のところ、RBD 症状の頻度 

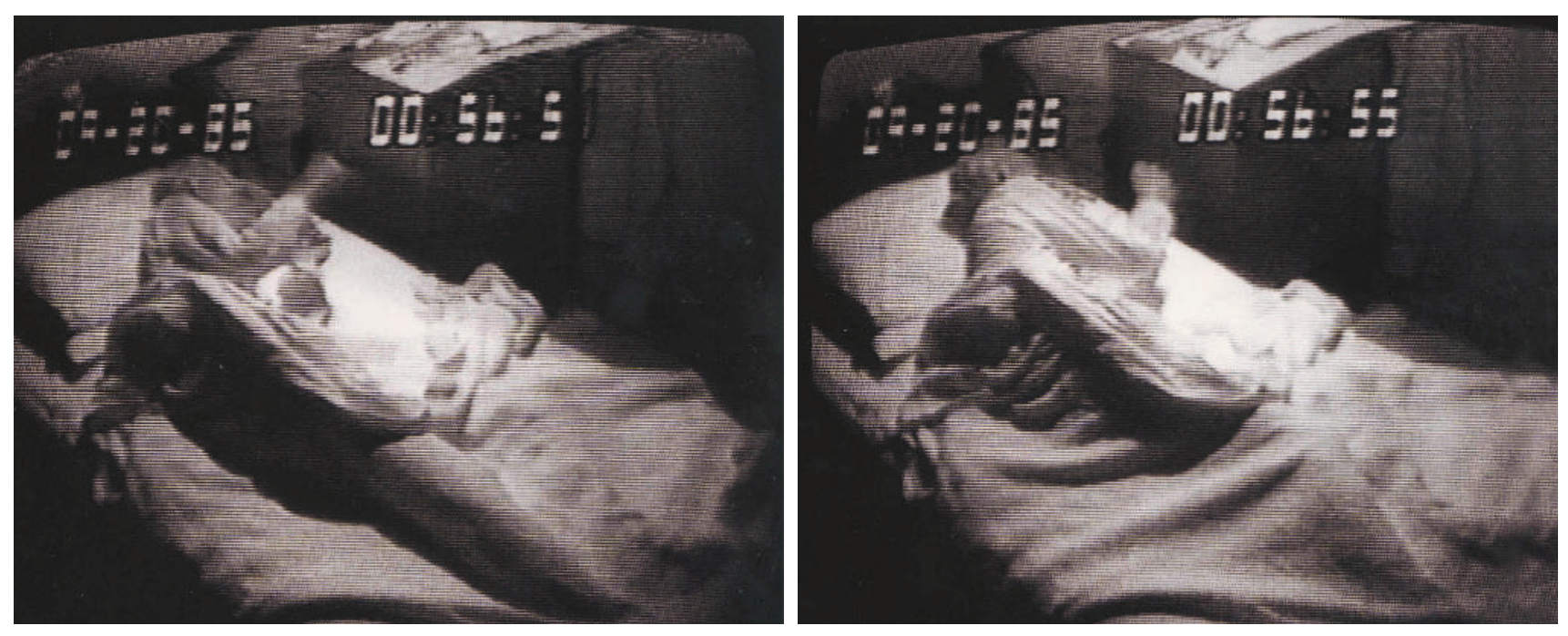

と、神経変性疾患になる可能性の大小、 また神経変性疾患が現れるまでの期間 には関連がないようだ。ミネソタ大 学ミネアポリスキャンパスの神経学者 Carlos Schenck と Mark Mahowald が調べた 26 人の RBD 患者のうち、18 人がパーキンソン病かそれに密接に関 連した病気になった

RBD との関係がわかってきた退行性 の病気には、共通する基本的特徵があ る。その特徵は、 $\alpha$-シヌクレインとよ ばれる脳内のタンパク質が誤って折り たたまれた状態になり、それが凝集し て凝集体を作ることにある。これらの 病気で $\alpha$ - シヌクレインタンパク質がど んな役割を果たしているかははっきり していないが、こうした病気はシヌク レイノパチーと総称される。

RBD 患者は、誤って折りたたまれ た $\alpha$-シヌクレインが関与する病気に なる可能性がかなり高い。たとえば Schenck は、担当した RBD 患者のうち 約 70\% がシヌクレイノパチーになった と述べている。RBD の発病からシヌクレ イノパチーの症状を示しはじめるまでは 平均で 13 年。ただし、その幅は 3 年か ら 29 年とかなりのばらつきがみられた。

ほかの医療センターも、同じような経 験を報告している。たとえば、Boeve は未発表の研究で 250 人の RBD 患者 を調べているが、その多くが Boeve の 睡眠クリニックにやってきたときには
すでにパーキンソン病か、それ以外の シヌクレイノパチーを発病していた。当 初はRBD の症状しかみられなかった者 も、その約半数が平均して 8 年後にシ ヌクレイノパチーになった。また、研究 のあいだに死亡した 27 人の患者のうち 26 人の脳で、シヌクレイノパチーであ ることを示す、レビ小体とよばれる $\alpha$ シヌクレイン凝集体が見つかっている。

RBD とシヌクレイノパチーにおそら く関係があるらしいことは、1990 年代 半ばまでに明確になった 2 。いし、こ の 2 つが関係している理由はわからな

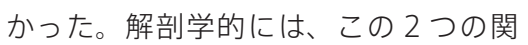
連はおかしな話だった。レム睡眠中の筋 肉の収縮しやすさや緊張は、体と脳上部 領域の間で情報を行き来させる複雑な 構造である、脳幹によって制御されるら しい。リヨン大学（フランス）の睡眠研 究者 Michel Jouvetが、1960 年代に それを証明している。Jouvetが、脳幹 の一部であるネコの橋（きょう）を傷つ けたところ、ネコはおとなしく眠らなく なり、レム睡眠時に想像上の獲物に忍び 寄るなどの動作をするようになった 3 。

しかし、科学界の定説によると、パー キンソン病は黒質の神経細胞の死が原 因で起こる。黒質は脳幹のなかでも橋 とは別の、中脳とよばれる上方の領域 にある。パーキンソン病に関連するとみ られる神経細胞はドーパミンという化 学物質を出す。ドーパミンは、脳のほ
かの場所ヘシグナルを伝える。つまり、 ドーパミンは動作のコントロールにか かわっている。パーキンソン病と黒質 のドーパミン産生細胞の死との関連は、 かなり広く認められている。たとえば、 パーキンソン病患者にドーパミンを投 与すると、少なくともしばらくは動作 のコントロールを劇的に改善すること ができる。また、死亡したパーキンソ ン病患者を解剖すると、黒質のドーパ ミン産生細胞の少なくとも $80 \%$ を失っ ていることがわかっている。

RBD とパーキンソン病には明白な関 係があるように思えるが、2つの疾患に 関連するとみられる脳領域がそれぞれ 異なっていることはどう説明すればよ いのだろうか。この分野の研究者たちは 今、定説の見直しが必要かどうか検討 している。新しい考えでは、RBDは脳 幹内あるいはその近くではじまる退行 性のプロセスの最初の兆候であり、この プロセスは脳の上部に向かって進行し、 脳のほかの領域へ広がるのだという。 Boeve が初めて提出したこの考えによ ると 4 、脳のより広範囲を冒す病気が初 期に襲う脳領域の損傷が原因で起きる のがRBD であり、この病気が黒質を冒 し、神経細胞を死なせる段階にいたって 初めて手足が不自由になるというのだ。

この考えはもっともらしいものの、 未解決の疑問は多い。たとえば、パー キンソン病患者のうち RBD になるのは 
3 分の 2 だけのようだが、それはなぜ なのか。全員がRBD になるはずではな いのかという疑問がある。しかし、こ の考えを支持する説得力ある証拠もい くつかある。とくに、フランクフルト 大学 (ドイツ) の神経解剖学者である Heiko Braak の研究がそうだ。

Braak はパーキンソン病患者 41 人の 脳を検死解剖し、詳細な解剖学的研究を 行った。彼はまた、神経変性疾患の臨床 記録はないが、検死解剖の結果、脳の一 部に「レビ小体」とよばれる物質がある ことがわかった 69 人の脳も調べた ${ }^{5}$ 。

\section{脳の上部へ広がる}

Braak は、レビ小体の出現は、明確で かなり予測可能なプロセスで進むらし いことを示した。彼はそのプロセスを 6 つの段階に分類する (右図を参照)。冒 される程度が最も軽い脳では、レビ小 体が現れるのは脳幹下部の明確な領域 に限定されている。3と 4 の段階では、 損傷は脳幹上部にも広がる。そして、段 階 5 と6では損傷は黒質に達し、最終 的には大脳皮質にも広がり、感情と知 的活動に関与する領域を冒す ${ }^{5}$ 。レビ小 体は増え、脳のいたるところに広がるよ うだが、脳の上部だけに現れるというこ とはない。レビ小体は、脳幹の下部に存 在しないかぎり、より上部に広がること はない。「パーキンソン病の運動機能障 害というつらい症状がみられるように なったときには、脳の損傷はとても進行 している」とBraak は説明する。

しかし、この病気の初期段階では明 白な症状がないらしいので、症状をみ て Braak がいうところのどの段階にあ るのかを判断するのはむずかしい。こ のため、レビ小体の広がりがパーキン ソン病と関連していると断定的に結論 することはできない。「これはもっとも らしくはあるが、仮説にすぎない。今 後は、初期段階に相当するなんらかの 症状があるのかどうかを調べなければ ならないだろう」とBraak は話す。

Braakの考えには、カリフォルニ ア州サニーベールにあるパーキンソン

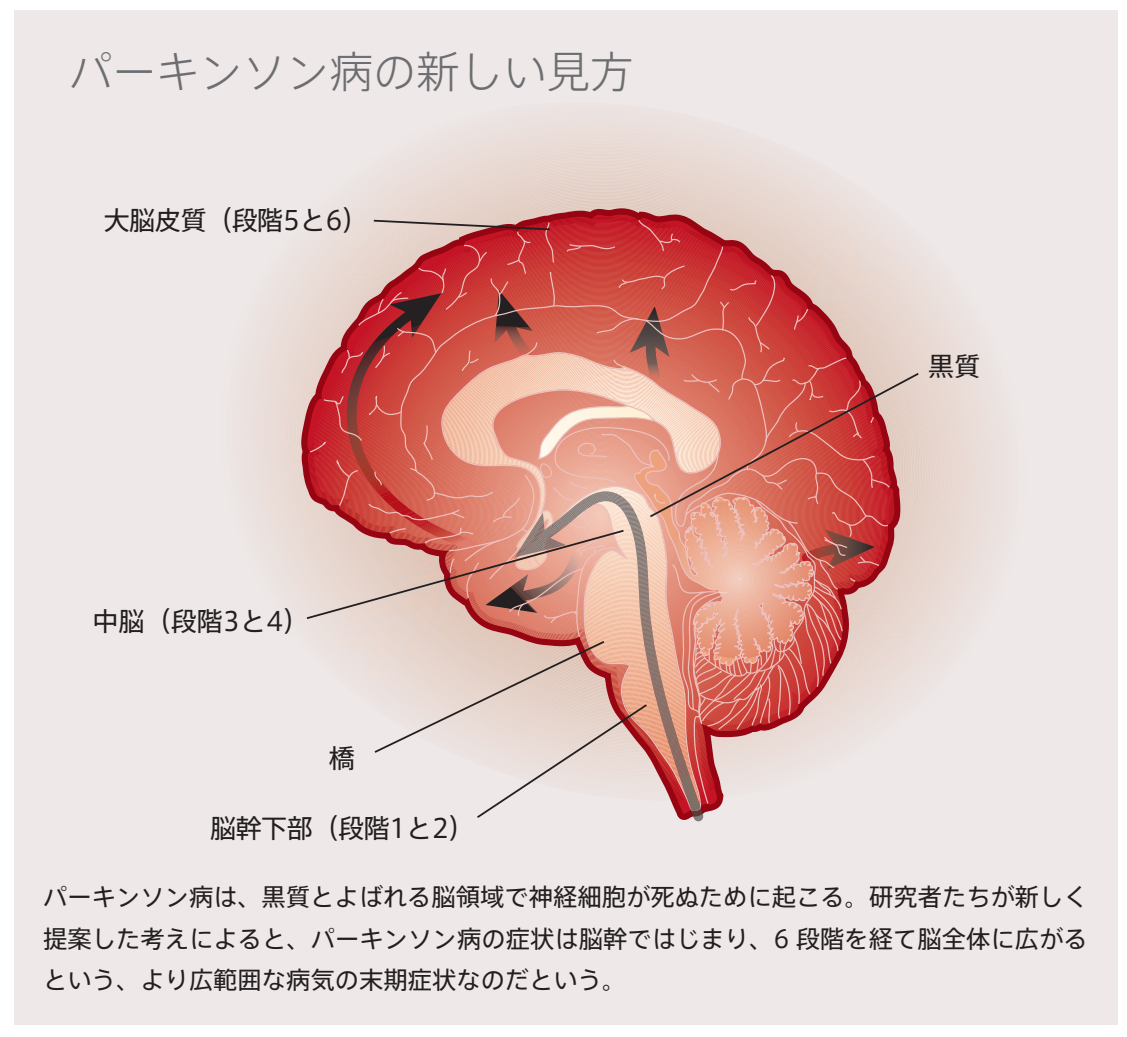

病研究所の所長で、臨床医兼研究者の William Langston も同調している。 Langstonは、患者たちが今のところ は典型的なパーキンソン病の一部には 分類されていない、さまざまな種類の 変わった症状を訴えることに気づいて いる。「臨床現場からみると、Braak の 考えに通じる印象が確かにある。パーキ ンソン病を考えるとき、私たちは木をみ て森をみるのに苦労しているのかもし れないと感じることがある。この場合、 個々の木は運動機能のさまざまなひど い障害のことだ」と Langston はいう。 Braakが見つけた初期段階が実際に パーキンソン病に関連があるなら、そ れは何を意味するのだろうか。そして、 たとえばRBDのような思いがけない 臨床症状を通じて、生きている脳の中 のレビ小体の広がりを追跡できるとす ればどうだろうか。神経科医のIlonka Eisensehrは「そうなれば、患者にパー キンソン病になる危険性がきわめて高 いという警告を、事前に与えることが できるかもしれない」と話す。今は個 人で医院を開業している Eisensehrが
ミュンヘン大学で取り組んだ研究は、 RBD とシヌクレイノパチーとの関連を 示す証拠の 1 つとなっている。

Eisensehrは、RBD と無関係の理由 で彼女の睡眠障害クリニックを訪れた 患者の一部が、レム睡眠の間に筋肉を いくらか緊張させることに気づいた。つ まり、彼らはまだ夢を行動に表してはい ないものの、睡眠時の筋肉のまひは不 完全だった。彼女は、こうした「潜在的」 RBD 患者のグループについて脳の画像 診断を行い、RBD 患者、パーキンソン 病患者、健常対照群と比較した。また、 脳幹上部にみられる「ドーパミントラン スポーター (輸送体)」とよばれるタン パク質のレベルを測定した。このタンパ ク質はドーパミン産生神経細胞にのみ 見つかるもので、患者のドーパミン産生 細胞の運命を調べることができる。

この結果、Eisensehr は明瞭な傾向 を見いだした。RBD 患者のドーパミン トランスポーターのレベルはかなり低 かったものの、さらに一番多くそれを 失っていたのはパーキンソン病患者だっ た。「潜在的」RBD 患者のドーパミント 
ランスポーターのレベルはまだましだっ たが、健常対照群よりは低く、ドーパミ ントランスポーターをどれだけ失ってい るかと、彼らがレム睡眠のあいだにどれ ほど筇肉を緊張させるかとは直接的に 相関した 6 。「ム筋弛緩をどれほど失っ ているかは測定可能であり、パーキンソ ン病のきわめて初期の指標となるかも しれない」とEisensehr は話す。

ドイツのマールブルク大学の Karin Stiasny-Kolster は、この仮説をさらに 補強する研究を行った。彼女が担当す る、症状の現れているRBD 患者と「潜 在的」RBD 患者、あわせて 30 人のほ とんどすべてが、パーキンソン病患者 にきわめてよくみられる症状である嗅 覚の障害をもっていることがわかった のだ ン病では脳の上方に段階的に損傷が広 がっていくとする Braak の仮説とよく 合う」とStiasny-Kolster は話す。に おいのシグナルは、Braakが脳幹下部 とともに段階 1 に分類した領域の 1 つ である嗅球に直接届く。

こうした証拠にもかかわらず、睡眠 神経学者の一部はまだ納得していない。 そのひとりがバルセロナ大学（スペイ ン) の Alex Iranzoだ。「9 年間に診察 したRBD 患者のうち、40\%が神経の 病気になったが、多くの場合、その病 気はシヌクレイノパチーではなかった。 RBD はまちがいなく解剖学的な病気 だが、分子学的に単一の説明がつくも のなのかどうか私にはわからない」と Iranzoは話す。

RBD 患者の脳で何が変調をきたして いるのかを正確に解明するためには、 明らかにもっと多くの研究を必要とす る。しかし、RBD 患者はパーキンソン 病やそのほかの回復不能な退行性の病 気になる危険性が高いことを、統計は 冷酷に示している。今のところ、RBD 患者の神経細胞を守る薬はなく、患者 がRBD と診断されたとき、パーキンソ ン病などになる可能性が高いことを告 知するべきかという倫理的ジレンマに 医師は苦しむ。

\section{告知すべきか}

Schenck は Eisensehr と同じように、 パーキンソン病などになる可能性が高 いことをRBD 患者に告げるべきだと 考えている。「そうすれば、RBD 患者 はクリニックと連絡を保ち、神経保護 薬の候補剤を試す治験などにいつかは 参加できるかもしれない」とSchenck はいう。多くの製薬企業が、そのよう な薬を開発しようとしている。まだ無 症状だがパーキンソン病になる危険性 が高い人たちが、うまく臨床試験に参 加できれば、製品を市場に早く出すこ とができるかもしれない。すでにパー キンソン病を発症している人たちは、 ドーパミン産生細胞のかなりの割合を すでに失っていて、守るべき神経細胞 がほとんど残っていないという状態に あるので、試験対象として実は理想的 ではない。「パーキンソン病のより初 期段階での研究が十分にできず、これ までの臨床試験は失敗が多かった」と Langstonは話す。

モントリオール大学 (カナダ) の神 経学者Jacques Montplaisir は、患者 から質問されないかぎり、この問題を あえてもちだしたくはないと考えてい る。彼は、神経変性疾患にかかってい ないRBD 患者に不必要な警告をしてし まうことを心配している。Montplaisir は、担当するRBD 患者の嗅覚をテスト するほか、これもパーキンソン病で失 われることの多い色覚のテストも行っ ている。そうすれば、パーキンソン病 になる危険性の高い人を見つけるのに 役立つだろうと考えるからだ。「こうし たテストをふまえたうえか、神経保護 薬が使えるようになったときにのみ、 患者に知らせることが倫理的に正当化 されると思う」と彼は話す。

ロンドンにあるパーキンソン病協会 の研究担当理事 Kieran Breen は「ま ずやるべきことは、RBD とパーキンソ ン病が関連している可能性を臨床医に 広く知らせていくことだ。そうすれば 臨床医は、RBD や嗅覚の障害のような 危険なシグナルに敏感になるだろう。
それが、兆候のある患者の経過を注意 深く観察することにつながる」と話す。 しかし、Breenは、患者がパーキンソ ン病であることを告げられるのは、運 動機能の症状がはじまってからにすべ きだとつけ加える。「そうしなければ、 関連の不確かさや、RBD の発病とパー キンソン病の発病まで長期にわたる ケースがあることも考えると、患者に とってフェアではない」という。

神経科医は現在、RBD患者が夢を 行動に表す症状を抑えるため、てんか ん治療に使われるクロナゼパムを処方 している。しかし、こうした処方は、 RBD という診断を受けた患者が、将来 自分は難病を発症するのかもしれない という不安とともに生きる際の助けに はならない。だが逆に将来、効果のあ る神経保護薬が開発されたときには、 RBD という早期警戒信号を受け取るこ とができた人は幸運な人ということに もなるのかもしれない。

「今はパーキンソン病研究の革新期 だ。私たちはこれまで、動作障害は黒 質の細胞の死と関係しているという考 えにとりつかれてきたが、これからは もっと幅広く考えなければならないの かもしれない」と Langstonは話す。 この悲惨な病気を理解し、どうすれば その進行を気づいた時点ですぐに止め ることができるかを知るには、RBDの ような早期警戒信号がまさに必要なの だとわかってもらえる日がやがてやっ てくる、と Langston は信じている。

Alison Abbott は Nature のヨーロッパ担当シ 二ア特派員。

1. Schenck, C. H., Bundlie, S. R. \& Mahowald, M. W. Sleep 26, A316 (2003).

2. Uchiyama, M. et al. Neurology 45, 709-712 (1995).

3. Jouvet, M. \& Delorme, J. F. C. R. Soc. Biol. 159, 895-899 (1965).

4.Boeve, B. F., Silber, M. H., Ferman, T. J., Lucas, J. A. \&

Parisi, J. E. Move. Disord. 16, 622-630 (2001)

5. Braak, H. et al. Neurobiol. Aging 24, 197-211 (2003).

6. Eisensehr, I. et al. Sleep 26, 507-512 (2003).

7. Stiasny-Kolster, K. et al. Brain 128, 126-137 (2005). 